\title{
Numerical study on bearing capacity of single stone column
}

\author{
K. S. $\mathrm{Ng}^{*}$
}

${ }^{*}$ Correspondence:

ngkokshien@ppinang.uitm. edu.my

Faculty of Civil Engineering, University Teknologi MARA,

Pulau Pinang Branch,

13500 Permatang Pauh,

Penang, Malaysia

\begin{abstract}
Stone columns are an efficient ground improvement technique for treating problematic soils. The confidence in the prediction accuracy of bearing capacity remains unsatisfactory. This paper aims to investigate the bearing capacity of single stone column using three-dimensional numerical analysis. Failure modes were observed and the effect of key parameters such as column's friction angle, undrained shear strength of surrounding soil and modular ratio were investigated. Numerical results showed bulging and a combination of bulging and punching are two dominant failure modes for the single stone column. Ultimate bearing capacity is mainly influenced by the column's friction angle and the undrained shear strength of the surrounding soil. Based on the results, a new prediction method is developed and compared reasonably well with the existing analytical solution and the field measurements.
\end{abstract}

Keywords: Single stone column, Ultimate bearing capacity, Numerical analysis, Failure modes

\section{Introduction}

Stone columns are widely applied in treating soft soils. The effectiveness of the treatment method is evidenced through the increase in bearing capacity and the reduction of compressibility of the treated ground. Most of the stone columns are constructed with the toe rested on the hard stratum which termed as end bearing columns, but occasionally floating stone columns are built with toe terminated at non-bearing stratum [1]. In soft soil treatment, when a stone column is axially loaded, it bulges and mobilizes passive soil resistance. The higher the initial horizontal stress state, the higher the passive soil resistance to prevent the column from bulging [2]. This failure mode can be seen in the end bearing column or when the column length is more than four times its diameter [3] or else the punching mode will prevail [4].

There are a few numbers of researchers who have derived the ultimate load for single stone column based on bulging failure mode [5-8]. Founded on the plasticity theory, Hughes et al. [9] applied the cylindrical cavity expansion theory as used in pressuremeter to estimate the ultimate bearing capacity of a column:

$$
q_{u l t}=\frac{1+\sin \varphi_{c}^{\prime}}{1-\sin \varphi_{c}^{\prime}}\left(\sigma_{r o}+4 c_{u}\right)
$$


where $\phi_{c}{ }_{c}$ is friction angle for column material, $\sigma_{r o}$ is the in situ radial stress, $c_{u}$ is the undrained shear strength of the soil. The approach is similar to Gibson and Anderson [10] and Vesic [11]. Based on a friction angle of $50^{\circ}$ for the column material and Rankine passive pressure theory, Wissmann [8], suggested that the ultimate bearing capacity of geopier can be predicted with:

$$
q_{u l t}=15.1 \sigma_{v}^{\prime}+39.3 c_{u}
$$

where $\sigma_{v}{ }^{\prime}$ is the effective vertical stress. Mitchell [12] proposed a simple method based on Vesic's cavity theory to predict the ultimate capacity of single stone column:

$$
q_{u l t}=N c_{u}
$$

where $N$ is the bearing capacity factor. Mitchell suggested a value for $N$ of 25 to be used. Based on the back calculation of field test, Barksdale and Bachus [4] found the $\mathrm{N}$ value to vary from 18 to 22, depending on the plasticity index and stiffness of the surrounding soil. Bergado and Lam [13] recommended the value of 15-18 for stone column in soft Bangkok clay. Datye and Madhav [14] reported the $N$ value to be generally above 50 .

Stuedlein and Holtz [15] reported a series of full-scale footing load tests conducted to evaluate the effect of aggregate gradation, column length, and compaction method for single stone column. It was found that the differences in compaction methods either vibration or tamping did not produce large differences in the ultimate bearing capacity and the value was controlled by the inherent variability in the stiffness and strength of the surrounding soils. On the other hand, White et al. [16] showed the tamping method would produce stiffer columns with higher friction angle, thus resulted in higher bearing capacity than that obtained with vibration method. Herle et al. [17] demonstrated the importance of maximum densification for the construction of the stone column. The literature has shown stone column friction angle can vary from $35^{\circ}$ to $52^{\circ}[6,18,19]$.

In spite of technological advances in column construction, accurate prediction in bearing capacity of the single stone column still remain a challenge. Thus, to enhance the understanding of the performance of the single stone column, this paper aims to investigate the bearing capacity of the single stone column in homogenous soil layer using numerical approach. Three-dimensional (3D) finite element modelling was carried out with associated flow rules adopted for the stone column material to take into account the dilatancy behaviour of compacted stone columns. The influence of compaction effort in terms of the different friction angle of stone column material was investigated for very soft to soft clay condition represented by different undrained shear strength. The results of this numerical study were compared against the analytical approach and the field recorded measurement.

\section{Numerical model and analysis}

Three-dimensional numerical analysis was carried out using commercial geotechnical software PLAXIS 3D. Figure 1 shows the numerical model for the study. Stone column diameter, $d$ of $1.0 \mathrm{~m}$ was installed in the soft clay. The column length is determined to be $5.0 \mathrm{~m}$. The horizontal and vertical boundary were set to be far enough to have caused no influence on the numerical results. A rigid footing of the same diameter as the stone 


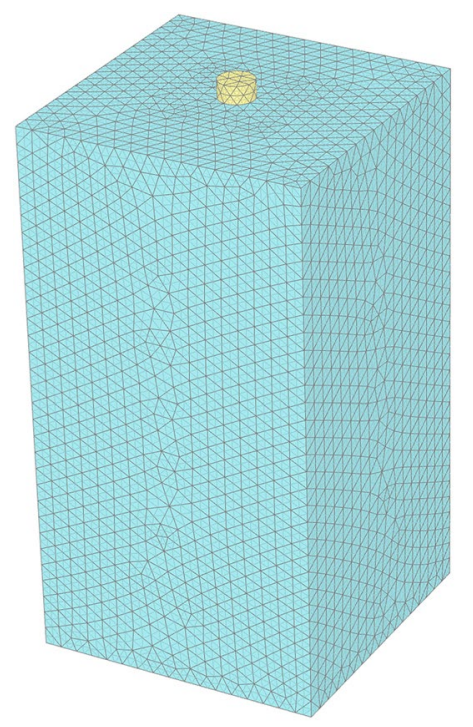

a

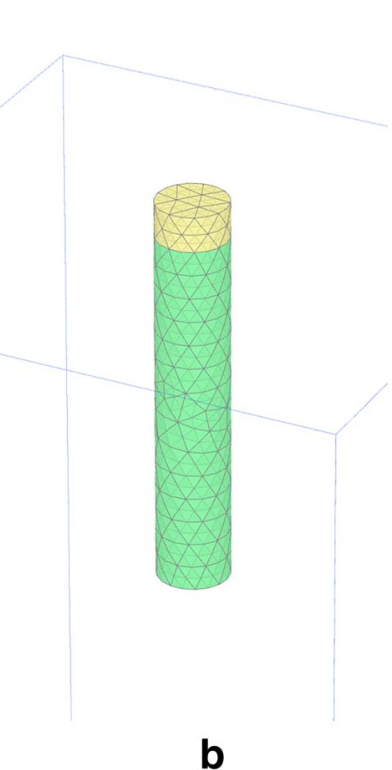

b

Fig. 1 a 3D numerical model; b stone column with rigid footing on top

column was placed on the column head. In this study, both stone column and soft soil were modelled as Mohr Coulomb (MC) soil model. Material properties are shown in Tables 1 and 2 for a series of tests. The undrained strength of the soft soil, $C_{u}$ varied from 5 to $40 \mathrm{kPa}$ and the effective friction angle for the column material, $\phi_{c}{ }^{\prime}$ varied from $35^{\circ}$ to $50^{\circ}$. Associated flow rules were adopted for column material where the dilation angle, is taken to be $\phi_{c}{ }^{\prime}-30^{\circ}$. The Young's modulus of the surrounding soil, $E_{s}$ is determined to be 150 times the undrained shear strength. The modular ratio, $m=E_{c} / E_{s}$ is taken as $10-40$ which is within the typical range; where $E_{c}$ is the Young's modulus of column material.

Table 1 Materials properties of the soil model

\begin{tabular}{llllllll}
\hline ID & Name & Type & $\begin{array}{l}\gamma_{b} \\
\left(\mathbf{k N} / \mathbf{m}^{\mathbf{3}}\right)\end{array}$ & $\boldsymbol{v}^{\prime}$ & $\begin{array}{l}\boldsymbol{C}_{\mathbf{u}} / \mathbf{c}^{\prime} \\
\left(\mathbf{k N} / \mathbf{m}^{\mathbf{2}}\right)\end{array}$ & $\begin{array}{l}\Phi^{\prime} \\
\left(^{\circ}\right)\end{array}$ & $\boldsymbol{\Psi}\left({ }^{\circ}\right)$ \\
\hline 1 & Soft soil & Undrained & 16 & 0.3 & $5-40$ & - & - \\
2 & Stone column & Drained & 18 & 0.3 & 1 & $35-55$ & $0-20$ \\
\hline
\end{tabular}

Table 2 Stiffness of surrounding soil and stone column

\begin{tabular}{|c|c|c|c|c|c|}
\hline \multirow{2}{*}{$\begin{array}{l}C_{u} \\
\left(\mathrm{kN} / \mathrm{m}^{2}\right)\end{array}$} & \multirow{2}{*}{$\begin{array}{l}E_{s} \\
\left(\mathrm{kN} / \mathrm{m}^{2}\right)\end{array}$} & \multicolumn{4}{|c|}{$E_{c}\left(\mathrm{kN} / \mathrm{m}^{2}\right)$} \\
\hline & & $10 E_{s}$ & $20 E_{s}$ & $30 E_{s}$ & $40 E_{s}$ \\
\hline 5 & 750 & 7500 & 15,000 & 22,500 & 300,000 \\
\hline 10 & 1500 & 15,000 & 30,000 & 45,000 & 600,000 \\
\hline 15 & 2250 & 22,500 & 45,000 & 67,500 & 900,000 \\
\hline 20 & 3000 & 30,000 & 60,000 & 90,000 & $1,200,000$ \\
\hline 25 & 3750 & 37,500 & 75,000 & 112,500 & $1,500,000$ \\
\hline 30 & 4500 & 45,000 & 90,000 & 135,000 & $1,800,000$ \\
\hline 35 & 5250 & 52,500 & 105,000 & 157,500 & $2,100,000$ \\
\hline 40 & 6000 & 60,000 & 120,000 & 180,000 & $2,400,000$ \\
\hline
\end{tabular}




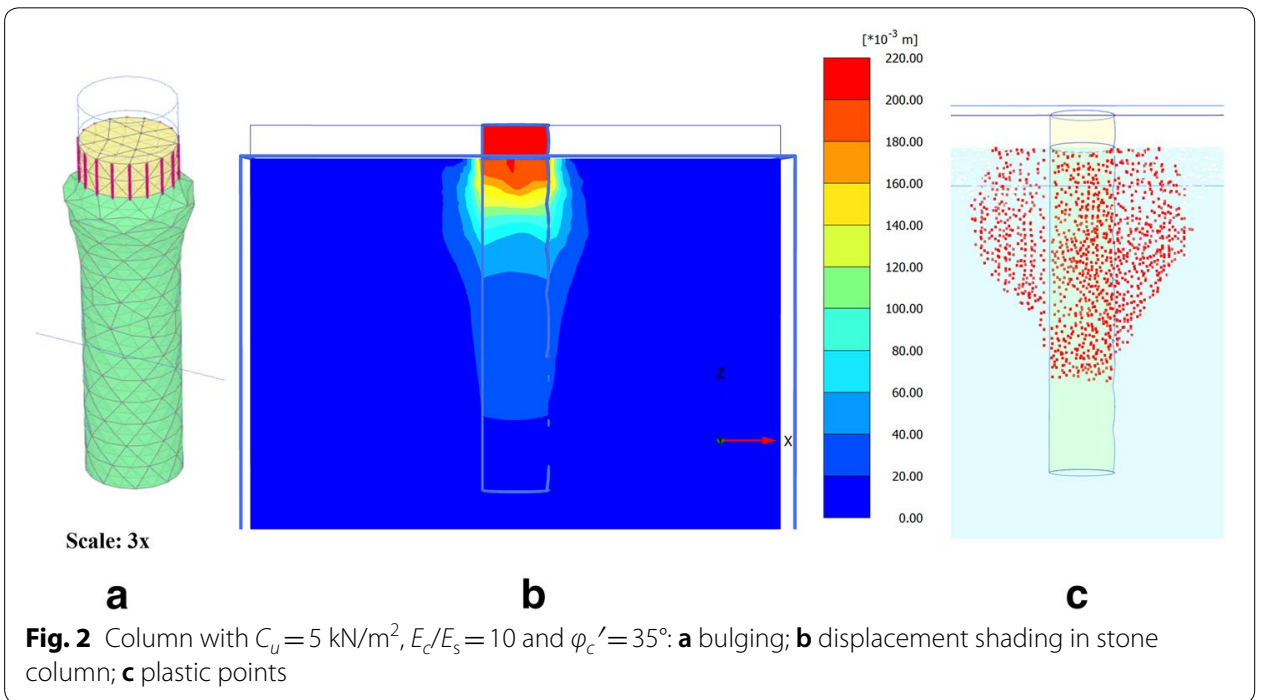

Initial stresses were generated by $K_{o}$ procedure with the proposed value of lateral earth pressure, $K=1.0$ for both the column and the soil reflecting wish-in-place approach was adopted in the model. The staged construction with the prescribed displacement approach was adopted to obtain the load that has caused the footing to deform $0.2 \mathrm{~m}$ vertically. Thus, the ultimate bearing capacity in this study is determined to be the pressure that has caused $20 \%$ strain relative to the column diameter.

\section{Failure mechanism}

In the analysis, the case with $C_{u}$ of $5 \mathrm{kN} / \mathrm{m}^{2}, E_{c} / E_{\mathrm{s}}$ of 10 and $\phi_{c}{ }^{\prime}=35^{\circ}$ is taken as the base case. Figure 2 shows the failure mechanism in the base case. Bulging is observed, and the maximum lateral displacement occurred at about one column diameter below the ground surface. Similar observation on a field load test was also being made by Bergado and Lam[13]. The bulging is noticed up to the depth of $3.5 \mathrm{~d}$. The toe penetration of the column is insignificant. A similar observation was made by Wehr [20]. Figure 2c shows the yielding occurred in the column as well as the surrounding soil. Radial expansion of upper column has resulted in the plastic zone up to $1 d$. Beyond that, the soil is still in the elastic state. It can be postulated that the ultimate bearing capacity of the column is solely derived through the maximum radial reaction or the confinement.

The load transfer mechanism is changed from the bulging in the upper column to a combination mode where bulging and punching failure take place at the same time as shown in the case with the higher friction angle of column i.e. $\phi_{c}{ }^{\prime}=50^{\circ}$ (Fig. 3). All other parameters remain the same as in the base case. Higher friction angle allows more loads to be transferred down to a deeper depth. Thus, the bearing capacity of the column is derived from both the radial expansion and the end resistance. It can be further deduced that the column length of 4 to 5 times the column diameter may not be the optimum length if the friction angle of the column is high even though the surrounding soil is very soft.

Figure 4 shows that there is not much difference in the failure mechanism when the undrained shear strength of the surrounding soil is increased to $C_{u}=40 \mathrm{kN} / \mathrm{m}^{2}$ while 


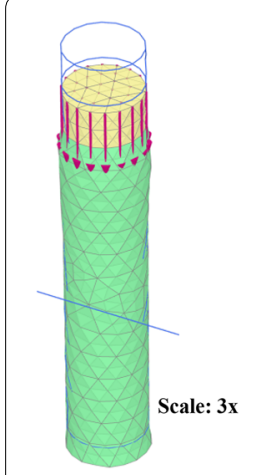

a

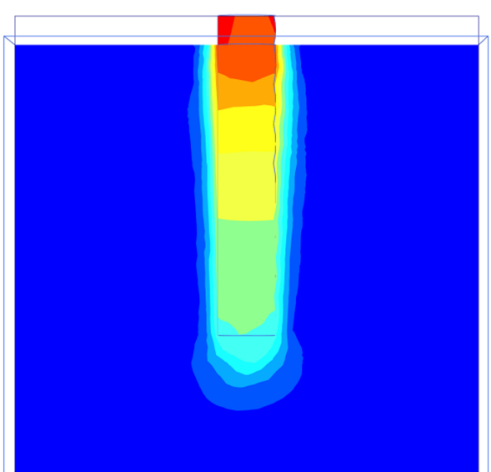

b

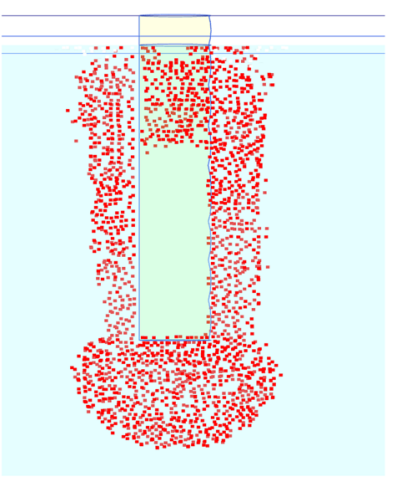

C

Fig. 3 Column with $C_{u}=5 \mathrm{kN} / \mathrm{m}^{2}, E_{c} / E_{s}=10$ and $\varphi_{c}{ }^{\prime}=50^{\circ}$ : a bulging; $\mathbf{b}$ displacement shading in stone column; c plastic points

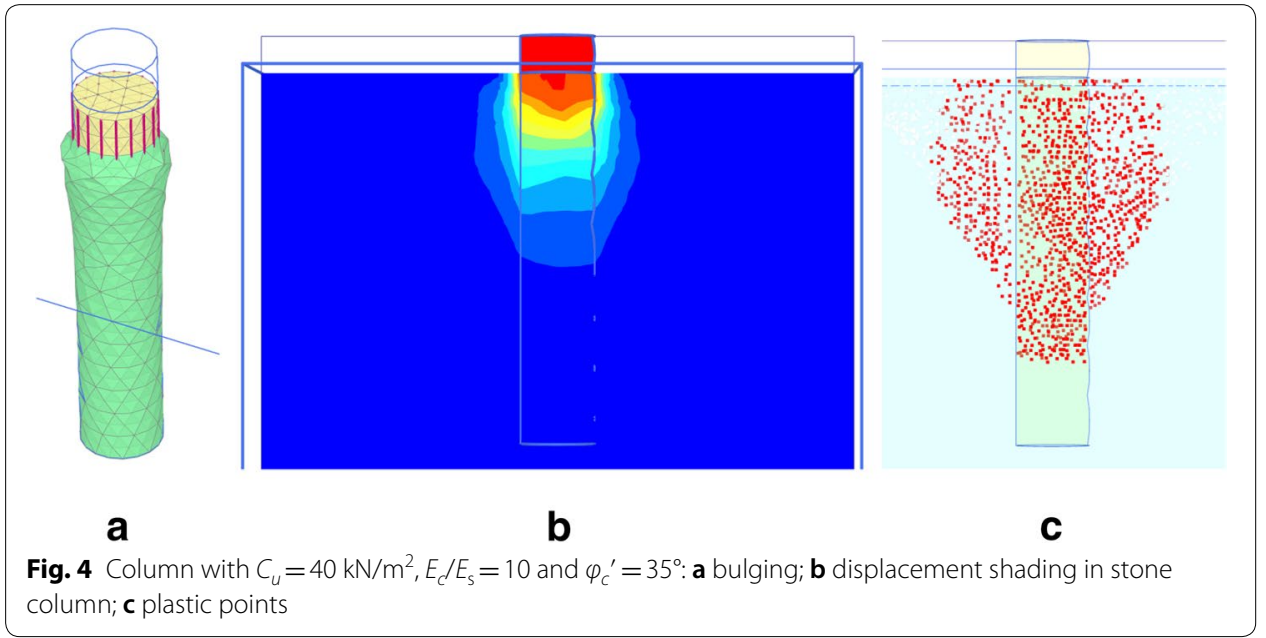

the other parameters remain the same as in the base case. However, when the $C_{u}$ is 40 $\mathrm{kN} / \mathrm{m}^{2}$ and the $\phi_{c}{ }^{\prime}$ is altered to a higher value i.e. $50^{\circ}$, then the radial expansion is more prominent than the case with lower $C_{u}$ and lower $\phi_{c}{ }^{\prime}$ as shown in Fig. 5, compared to Fig. 3. There is more yielding around the column, but less toe penetration and less yielding below the toe. Another finding in this study is that the modular ratio does not play an important role in governing the failure mechanism and thus the results due to the changes in the modular ratio are not shown here.

\section{Bearing capacity results}

Load-displacement curves for cases with $E_{c} / E_{s}$ of 10 and $C_{u}$ of $5,10,15,20,25,30,35$, and $40 \mathrm{kN} / \mathrm{m}^{2}$ are shown in Fig. 6 . No peak strength is noticed in all the curves and all the results show strain hardening behaviour. The similar displacement response is found in all other cases with $E_{c} / E_{s}$ of 20,30 and 40 . The results indicate the significant influence of the column's friction angle and the undrained shear strength of the surrounding soil 


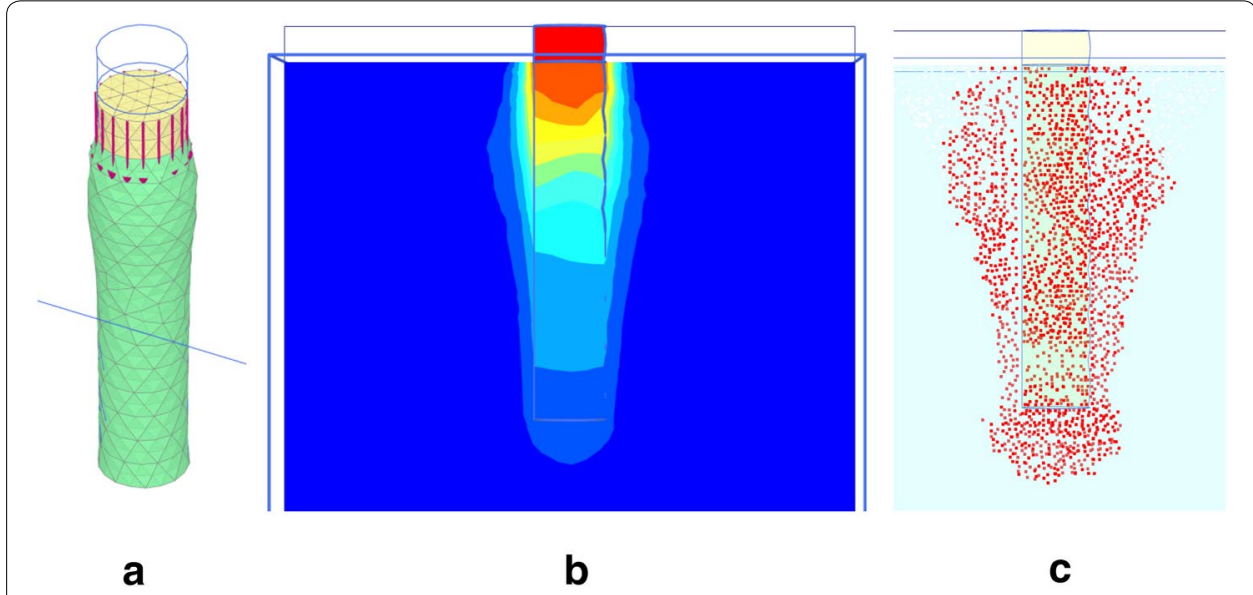

Fig. 5 Column with $C_{u}=40 \mathrm{kN} / \mathrm{m}^{2}, E_{c} / E_{s}=10$ and $\varphi_{c}{ }^{\prime}=50^{\circ}$ : a bulging; b displacement shading in stone column; c plastic points

where higher ultimate bearing capacity, $q_{u l t}$ is obtained when the values of these parameters are increased.

The results of ultimate bearing capacity are plotted in terms of $q_{u l t}$ versus $C_{u}$ as shown in Fig. 7. Near linear straight lines are obtained for all cases with different column's friction angles and different modular ratios. When the plots made in terms of $q_{u l t}$ versus $C_{u}$ versus $\phi_{c}^{\prime}$ (Fig. 8), it is clearly seen that the influence of modular ratio is small and can be ignored especially when the modular ratio is larger than 20. Similar results are obtained in Ng and Tan [21] where unit cell model was used to simulate infinite column grid.

From the results of Fig. $7 \mathrm{a}$ and in view of negligible influence of the modular ratio, the relationship of the ultimate bearing capacity, the undrained shear strength of the surrounding soil and the friction angle of the column can be written as:

$$
q_{u l t}=\left(\varphi_{c}^{\prime}-15\right) \cdot C_{u}+50
$$

Comparison was made against Eqs. (1) and (2) developed by Hughes et al. [9] and Wissmann [8] respectively as shown in Fig. 9. The friction angle of the column material was taken as $50^{\circ}$. It was found that the above relationship produces higher ultimate bearing capacity compared to Hughes et al. [9] but lower than that by Wissmann [8].

Further comparisons were made with field measurements from the single column load test as shown in Fig. 10. The results of the present study lied between the field measurements. However, the testing conditions for each testing are different. For instance, the footing embedment depth for Datye and Madhav [14] was $1.0 \mathrm{~m}$ while it was $0.61 \mathrm{~m}$ in Studlein and Holtz [15] and $0 \mathrm{~m}$ for Bergado and Lam [13]. Assumptions were made to the friction angle of column when the information is not available.

\section{Conclusion}

Three-dimensional numerical analysis was carried to evaluate the performance of a single stone column in term of its bearing capacity. The conclusions that can be drawn from this study include: 

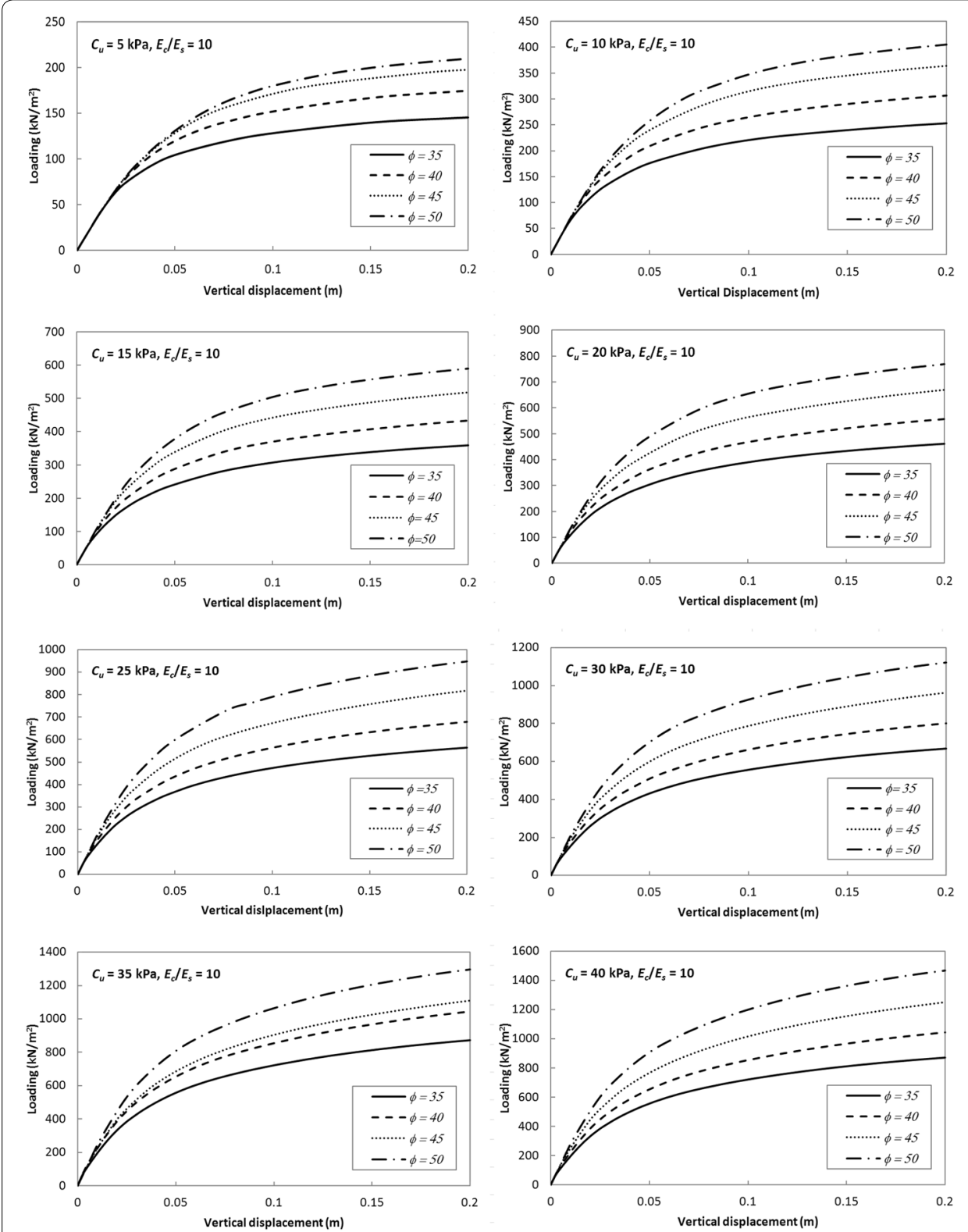

Fig. 6 Load-displacement curves for cases with $E_{c} / E_{s}=10$

1. Bulging or combination of bulging and punching can happen to the single stone column having the same length. The failure modes are influenced by the value of column's friction angle and not much by the shear strength of the surrounding soil and the modular ratio.

2. The ultimate bearing capacity of the single stone column is influenced by the column's friction angle and the undrained shear strength of the surrounding soil. The effect of modular ratio is small and can be ignored, especially when $E_{c} / E_{s}$ is larger than 20 .

3. Strain hardening behavior is noticed with no distinct peak strength. 

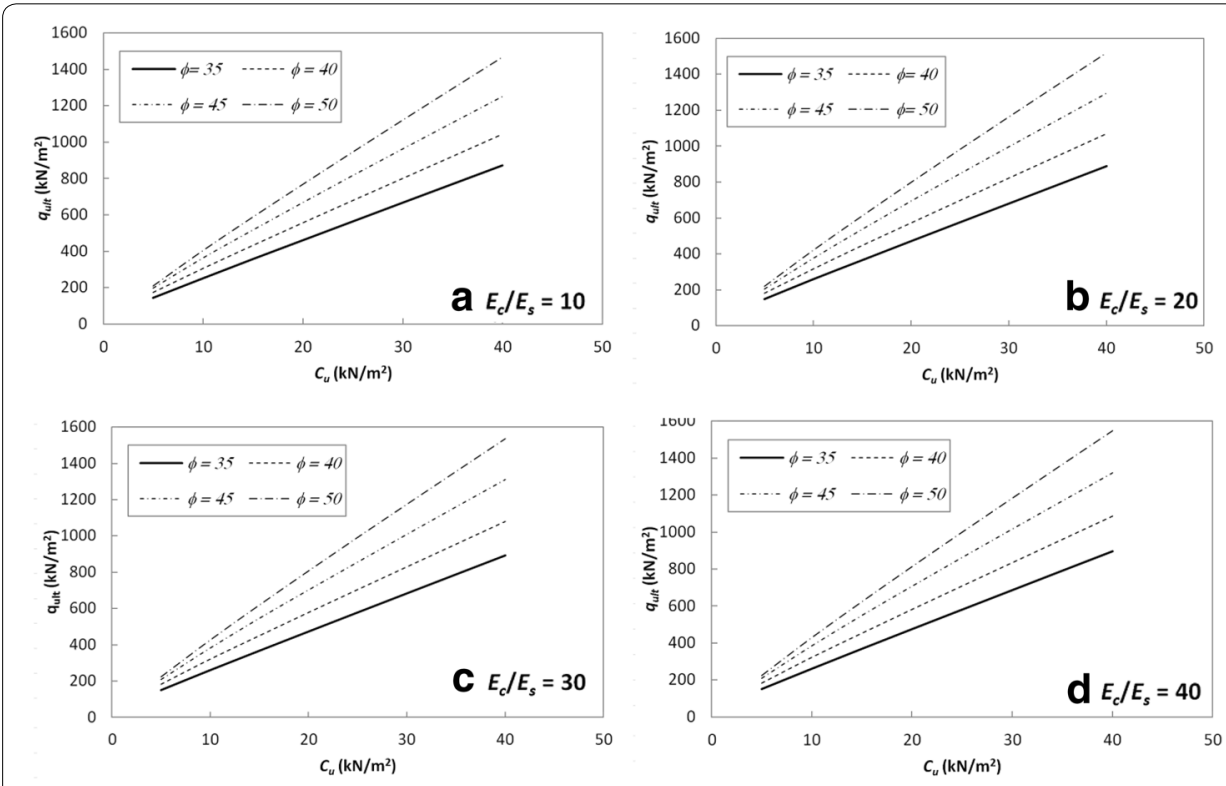

Fig. 7 Ultimate bearing capacity versus undrained shear strength
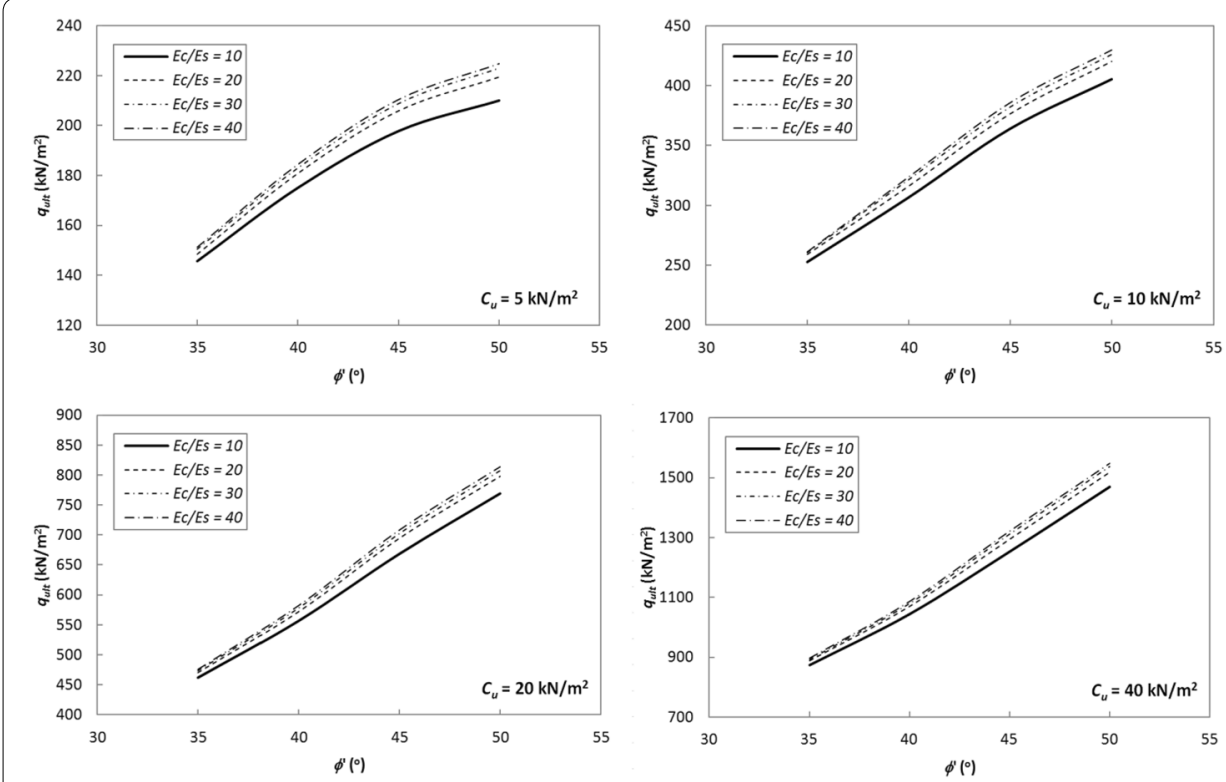

Fig. 8 Ultimate bearing capacity versus friction angle of column material 


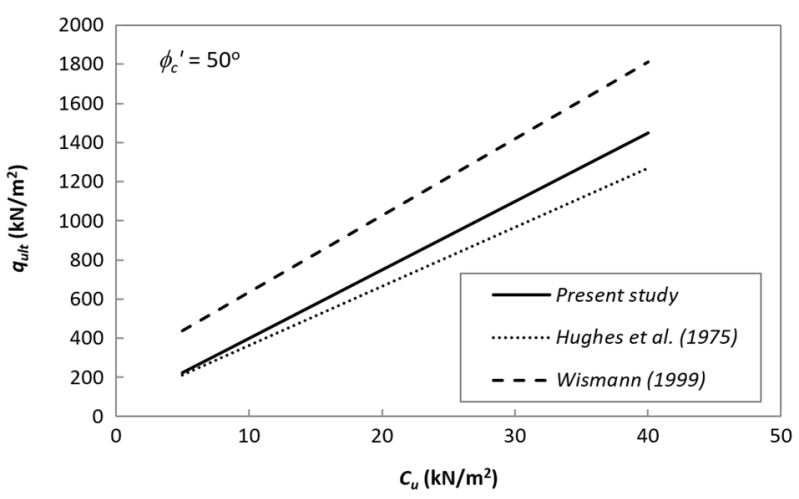

Fig. 9 Comparison with analytical solutions

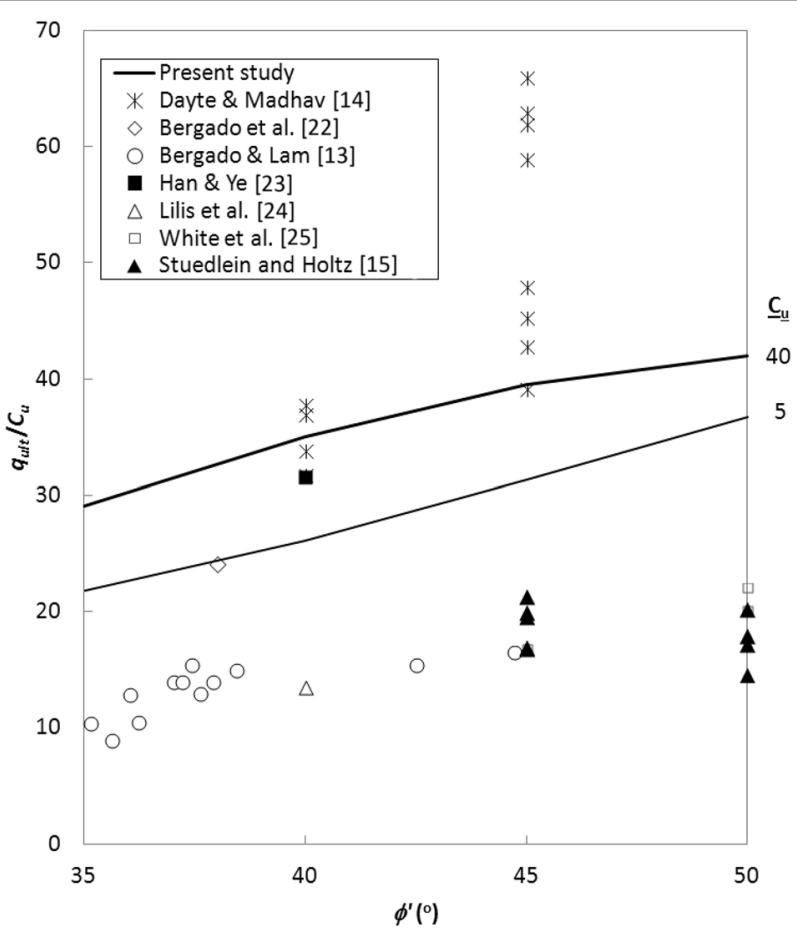

Fig. 10 Comparison with field measurements

4. By ignoring the influence of modular ratio, a prediction equation was established. It compared well with the analytical solution developed by Hughes et al. [9] and Wissmann [8]. Further field test validation also shows reasonable agreement when the prediction equation was used.

Authors' contributions

This study and the paper was solely completed by KSN. The author read and approved the final manuscript.

Competing interests

The author declares that he has no competing interests.

Ethics approval and consent to participate

Not applicable. 


\section{Publisher's Note}

Springer Nature remains neutral with regard to jurisdictional claims in published maps and institutional affiliations.

Received: 14 March 2018 Accepted: 30 May 2018

Published online: 04 June 2018

\section{References}

1. Ng KS, Tan SA (2014) Design and analyses of floating stone columns. Soils Found 54(3):478-487

2. Kirsch F (2006) Vibro stone column installation and its effect on ground improvement. In: Numerical modelling of construction processes in geotechnical engineering for urban environment: proceedings of the international conference on numerical simulation of construction processes in geotechnical engineering for urban environment. Bochum, Germany, p 115

3. Hughes JMO, Withers NJ (1974) Reinforcing of soft cohesive soils with stone columns. Ground Eng 7(3):42-49

4. Barksdale RD, Bachus RC (1983) Design and construction of stone columns. Federal Highway Administration Office of Engineering and Highway Operations

5. Brauns J (1978) Initial bearing capacity of stone columns and sand piles. Soil reinforcing and stabilizing techniques in engineering practice, Sydney, pp 1497512

6. Greenwood DA (1970) Mechanical improvement of soils below ground surface. In: Proc., ground engineering conf., Institution of civil engineers, London, p 11-22

7. Van Impe WF, Madhav MR, Vandercruyssen JP (1997) Considerations in stone column design. In: Ground improvement geosystems: densification and reinforcement: proceedings of the third international conference on ground improvement geosystems, London, pp 190-196

8. Wissmann KJ (1999) Bearing capacity of GEOPIER—supported foundation systems. Technical Bulletin, No.2, GEOPIER Foundation Co., Inc., Scottsdale, AZ

9. Hughes JMO, Withers NJ, Greenwood DA (1975) A field trial of the reinforcing effect of a stone column in soil. Geotechnique 25(1):31-44

10. Gibson RE, Anderson WF (1961) In situ measurement of soil properties with the pressuremeter. Civil Eng Public Works Rev 56:615-618

11. Vesic AS (1972) Expansion of cavities in infinite soil mass. J Soil Mech Found Division 98(3):265-290

12. Mitchell JK (1981) Soil improvement-state of the art report. In: Proceedings, 11 th int conf on SMFE. pp 509-565

13. Bergado DT, Lam FL (1987) Full scale load test of granular piles with different densities and different proportions of gravel and sand on soft Bangkok clay. Soils Found 27(1):86-93

14. Datye KR, Madhav MR (1988) Case histories of foundations with stone columns. In: Proceedings of the 2nd international conference on case histories in geotechnical engineering, St. Louis, MO, 1-5 June, Paper No 5, p 37

15. Stuedlein AW, Holtz RD (2012) Bearing capacity of spread footings on aggregate pier reinforced clay. J Geotech Geoenviron Eng 139(1):49-58

16. White DJ, Wissmann KJ, Barnes AG, Gaul AJ (2002) Embankment support: a comparison of stone column and rammed aggregate pier soil reinforcement. In: Presented, transportation research board, 81st meeting, Washington, DC, January, pp 13-17

17. Herle I, Wehr JJ, Arnold M (2008) Soil improvement with vibrated stone columns-influence of pressure level and relative density on friction angle. In: Geotechnics of soft soils: focus on ground improvement. Taylor \& Francis

18. Goughnour RR, Barksdale RD (1984) Performance of a stone column supported embankment. In: Proceedings of the international conference on case histories in geotechnical engineering, p 25

19. Fox NS, Cowell MJ (1998) Geopier foundation and soil reinforcement manual. Geopier Foundation Company Inc., Scottsdale

20. Wehr J (2004) Stone columns-single columns and group behavior. In Proceedings of 5 th international conference on ground improvement technologies, Kuala Lumpur, pp 329-340

21. Ng KS, Tan SA (2015) Simplified homogenization method in stone column designs. Soils Found 55(1):154-165

22. Bergado DT, Rantucci G, Widodo S (1984) Full scale load tests of granular piles and sand drains in the soft Bangkok clay. In: Proceedings international conference on in situ soil and rock reinforcement, Paris, pp 111-118

23. Han J, Ye S (1991) Field tests of soft clay stabilized by stone columns in coastal areas in China. In: 4th International conference on piling and deep foundations, Stresa, pp 243-248

24. Lillis C, Lutenegger AJ, Adams M (2004) Compression and uplift of rammed aggregate piers in clay. In: GeoSupport 2004: drilled shafts, micropiling, deep mixing, remedial methods, and specialty foundation systems, pp 497-507

25. White DJ, Pham HT, Hoevelkamp KK (2007) Support mechanisms of rammed aggregate piers. I: experimental results. J Geotech Geoenviron Eng 133(12):1503-1511 